$\xi=$ 監

\title{
Assessment of water quality in parts of industrial area of Nnewi north local government area, southeast, Nigeria
}

\author{
Ifeanyichukwu A Kenechukwu'*, Elizabeth Okoyeh"1, Chukwuebuka Emeh ${ }^{1}$ \\ ${ }^{1}$ Department of Geological Sciences, Nnamdi Azikiwe University Awka, Nigeria \\ *Corresponding author E-mail:kene4all@yahoo.com
}

\begin{abstract}
Industrial pollution in Nnewi-North local Government Area, Anambra state, South Eastern Nigeria has become a major environmental concern due to unregulated discharge of industrial emissions and effluents into the environment. However, the paucity of environmental data and research from this area makes it difficult to ascertain the effect of the industrial activities on the surrounding environment. For this reason, it became imperative to assess the impact of the industrial activities on the quality of the surrounding surface and groundwater for agricultural and domestic purposes. To this end, an integration of geological, and geochemical method of analyses was adopted. The geology of the study area was determined through surface geological mapping, 22 groundwater water samples, and 3 surface water samples were collected within the study area following American Public Health Association (APHA) procedures. The sample collections were done in such a way that consider lateral and during the dry season. Atomic Absorption Spectroscopy (AAS), titrimetric and gravimetric, analytical method was used to ascertain the chemical composition of the water. The laboratory and field results were analyzed by employing several geochemical indices calculations, and inferential and summary statistics. Results from groundwater indices such as GWQI, HPI, HEI and Cd calculated with respect to WHO, 2011 and NSDWQ for both dry seasons revealed that the groundwater was contaminated, and unfit for drinking. Then from the surface water samples result of irrigation quality indices such as TH, MH, SAR, RSBC, Na\% and PI calculated for dry season, indicated that the surface water is fit for irrigation for all irrigation indices expect RSBC and MH. From the statistics of PCA and T-test it was statistical proven that the source of contamination of surface and groundwater was anthropogenic (that is from industrial waste) and geogenic. Since the groundwater is contaminated, it is therefore recommended that the water should be treated before consumption.
\end{abstract}

Keywords:Anthropogenic Waste; Contaminated; Groundwater; Surface Water.

\section{Introduction}

Industrialization is considered the cornerstone of development strategies due to its significant contribution to the economic growth and human welfare, but it carries inevitable costs and problems in terms of pollution of the air and water resources (Akarinwo and Gwin, 2006). Rapid industrialization upsets the environment in different ways, through discharge of effluents as wastewater into the surrounding water bodies and causing serious problems to the environment. Industrial wastes are mostly inorganic in nature in the sense that they contain minerals or heavy metals in large quantities (Backman et al., 1997). Effluents coming from different industrial and commercial establishments pose a serious threat to the environment, particularly in urban and semi urban areas. It becomes the source of pollution to soil, groundwater and surface water (Lakhimi, 2010). Heavy metal contamination of urban topsoil is usually deduced from man-made sources such as emissions from automobile exhaust, waste incineration, land disposal of wastes, agricultural activities, emissions from industrial processes and wet or dry atmospheric deposits Industries are the sources of all major pollutions including air, water and land (Sarker, 2014). Industrial wastes are peculiar to individual industries as each sector produce its own particular combination of pollutants, for example, waste from plastic industries contains cadmium and chromium. Untreated or partially treated industrial wastewater contains algae materials, non-biodegradable organic matter, heavy metals and other toxicants that deteriorate the environment and the receiving water bodies (Akarinwo and Gwin, 2006). Water pollution is a serious problem globally. it involves the discharge of dissolved or suspended substances into groundwater, streams, rivers or oceans. The quality of groundwater within a region is governed by processes such as dissolution, precipitation, ion exchange processes, and the residence time along the flow path. Weathering processes, soil erosion, and anthropogenic effects such as urban, industrial, agricultural, and human activities are also factors which affects the groundwater quality (Mahajan, 2012).

Nnewi town houses most of the major small and medium scale industrial clusters in south-eastern Nigeria. The industrial clusters in Nnewi town of Anambra State includes: automobile, metals, paints and battery production (Onuukwo et al., 2014). Nnewi has been described as the Japan of Africa because of a wide range of automobile fabrications. It also harbours some food processing industries that produce vegetable oil, soaps, plastic tanks/Jerry cans, feeds and engine oil. A report has already been made that these industrial activities are responsible for polluting the surrounding land surface in Nnewi (Orisakwe et al., 1999). Therefore, environmental contamination by industrially discharged effluents is an emerging problem in Nnewi town. Hence, this study is focused on Potential Toxic Elements 
(PTEs)investigation of Nnewi industrial area, to achieve UNEP and WHO (Vasanthavigar et al., 2010), intention of having access to water in adequate quantities, and quality to maintain health and sustainable environment.

The study area is part of Nnewi North LGA of Anambra state is located about $22 \mathrm{~km}$ South East of Onitsha and lies within latitudes $5^{0}$ $580^{\mathrm{l}} \mathrm{N}$ and $6^{0} 30^{\mathrm{l}} \mathrm{N}$ and longitudes $6^{0} 520^{\mathrm{l}} \mathrm{E}$ and $6^{0} 57^{\mathrm{l}} \mathrm{E}$. The altitude ranges from $105 \mathrm{~m}$ to $300 \mathrm{~m}$ above sea-level. It is a commercial city, the second largest city in Anambra State, Nigeria (Obeta, 2015), its commercial nature influences its rapid urbanization and as a metropolitan city, it comprises four autonomous quarters: Otolo, Uruagu, Umudim, and Nnewichi (Fig. 1). The study area covers about $128 \mathrm{~km}^{2}$, with an estimated population of 121,063 according to the Nigerian population commission.

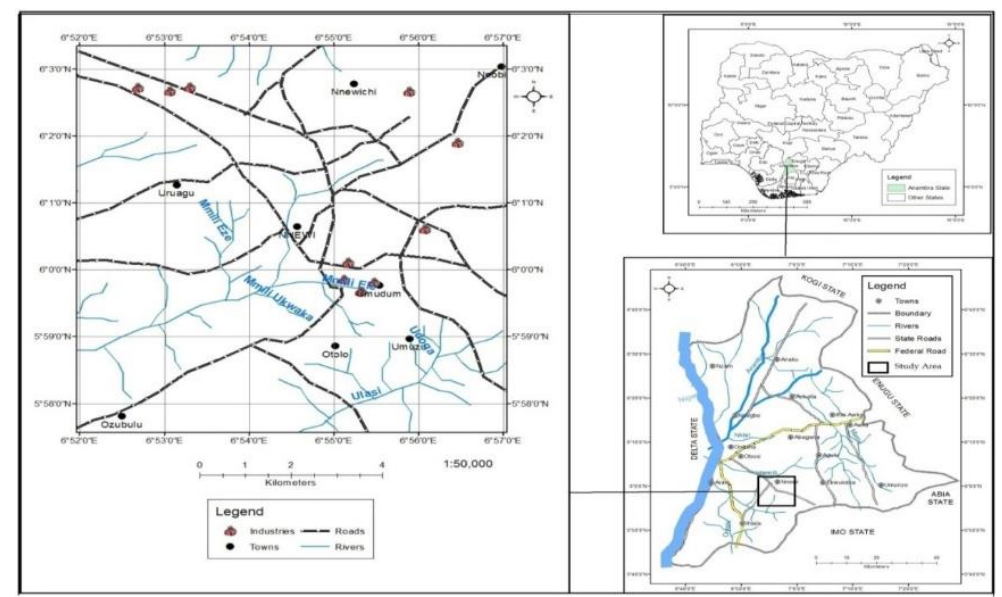

Fig. 1: Location and Accessibility Map of Study Area.

\section{Geology and hydrogeology of the study area}

The study area is underlain by two formation; Eocene Nanka Sands Formations (Ameki group) and Quaternary Ogwashi-Asaba formation (Nwajide, 2013; Reyment, 1965). In the study area it is a sequence of poorly consolidated, poorly sorted, friable, medium to coarse sands of Eocene age. The formation contains thin band of clay stone, siltstone and shale. The units have good porosity and permeability. The sandstone unit is aquiferous (Nwajide, 1979). Overlying the Nanka Sands is the Ogwashi-Asaba Formation. This consists of intercalation of lignite and clays.

The Ogwashi-Asaba Formation consists of multiple aquifers and a depth to water table ranging from 50 to $110 \mathrm{~m}$. Within it, transmissivity values of 37.54 to $95.5 \mathrm{~m}^{2} /$ day and a yield of up to 5litres/sec has been recorded (AN-NEWMAP, 2017). Nanka Sand is very aquiferous and this accounts for the numerous water boreholes drilled into the formation. Water levels occur at shallow depths in the plains and valley courses and at greater depths in the highland areas (Okpoto, 2017). This indicates that the extent and distribution of groundwater within the study area is controlled predominantly by lithology, topography and nearness to source of recharge which is, from surface water. Infiltration from rainfall as well as surface runoff also plays significant role (AN-NEWMAP, 2017).

\section{Methods}

Geological field mapping, by surface traversing, contact identification and detailed outcrop studies, was done to identify the lithologies outcropping in the study area followed by Water sample collection which was done in line with the guidelines of American Public health Association (APHA). A total of twenty (22) groundwater samples was collected from groundwater (boreholes). Three (3) streams (Mmili Eze, Mmili Ele and Mmili Ukwaka) were collected for dry season. The water samples were analysed for physical parameters insitu such as pH, Electrical Conductivity and total Dissolved Solid was measured with a pH. meter (Hanna model H1991300), Conductivity meter (Model DDS-307) and TDS meter (TDS139 TESTER) instruments respectively. Laboratory analysis for the concentration of cations and heavy metals including Chromium, Nickel, Arsenic, Iron, Lead, Cadmium, Calcium, Magnesium, Mercury, Aluminium and Potassium was carried out using Varian AA240 Atomic Absorption Spectrophometer (AAS) while chloride, bicarbonate and total hardness was analysed using titrimetric method, and sulphate was analysed using Gravimetric method. The results of groundwater samples were compared with the World Health Organization (WHO), (1996), standards and Nigeria drinking water standard for water quality in order to assess the quality status of the available water sources.

\subsection{Groundwater quality analysis}

\subsubsection{Groundwater quality index (GWQI)}

Groundwater quality index is defined as a technique of rating that provides the composite influence of individual water quality parameters on the overall quality of water for human consumption.

The groundwater quality was measured using the following equation for GWQI (Vasanthavigar et al., 2010) with respect to national and international standards.

$\mathrm{GWQI}=\sum \mathrm{SI}_{\mathrm{i}}=\sum\left(\mathrm{W}_{\mathrm{i}} \times \mathrm{q}_{\mathrm{i}}\right)=\sum\left[\left(\frac{\mathrm{w}_{\mathrm{i}}}{\sum_{\mathrm{n}}^{\mathrm{i}=1} \mathrm{w}_{\mathrm{i}}}\right) \times\left(\frac{\mathrm{C}_{\mathrm{i}}}{\mathrm{S}_{\mathrm{i}}} \times 100\right)\right]$

Where $\mathrm{C}_{\mathrm{i}}$ is concentrations of each parameter, and $\mathrm{S}_{\mathrm{i}}$ is the limit values, $\mathrm{w}_{\mathrm{i}}$ is the assigned weight according to its relative importance in the overall quality of water for drinking purpose (Table 1 ), $\mathrm{q}_{\mathrm{i}}$ is the water quality rating $\mathrm{W}_{\mathrm{i}}$ is the relative weight, $\mathrm{SI}_{\mathrm{i}}$ is the sub-index of ith parameter. 


\subsubsection{Heavy metal pollution index (HPI)}

The heavy metal pollution index method has been established by assigning the weightage (Wi) for selected parameter and selecting the groundwater parameter on which the index has to be based. The rating is nearly zero to one, and its selection reveals the significance of each water quality parameter. It can be defined as inverse of the recommended standard (Si) for each parameter (Mohan et al., 1996). The concentration limits (i.e., the highest permissible value for drinking water (Si) and maximum desirable value (Ii) for each parameter) were taken from the WHO for this study. Heavy metal pollution index (HPI) was used for assigning a rating or weightage (Wi) for each selected parameter, is computed using the following equation (Mohan et al., 1996).

HPI $=\frac{\sum_{\mathrm{i} \equiv 1}^{\mathrm{n}} \mathrm{W}_{\mathrm{i}} \mathrm{Q}_{\mathrm{i}}}{\sum_{\mathrm{i} \equiv 1}^{\mathrm{n}} \mathrm{W}_{\mathrm{i}}}$

Where, Wi is the sub-index of the ith parameter and Wi is unit weight of the ith parameter and $\mathrm{n}$ is the number of parameters. The subindex Qi shall be computed by

$\mathrm{Q}_{\mathrm{i}}=\sum_{\mathrm{i}=1}^{\mathrm{n}} \frac{\left[\mathrm{M}_{\mathrm{i}}(-) \mathrm{I}_{\mathrm{i}}\right]}{\left(\mathrm{S}_{\mathrm{i}}-\mathrm{I}_{\mathrm{i}}\right)} \times 100$

Where, Mi, Ii, and Si donate for the 'monitored value', 'ideal value' and 'standard values' of the ith parameter respectively. The negative sign (-) denotes for numerical difference of the two values, ignoring the algebraic sign.

\subsubsection{Heavy metal evaluation index (HEI)}

Heavy metal evaluation index method is consistent with the HPI method, which gives an insight to the overall quality of the groundwater with respect to heavy metals (Edet and Offiong, 2002; Prasad and Jaiprakas, 1999), and it will be calculated by following this equation. $\mathrm{HEI}=\sum_{\mathrm{i} \equiv 1}^{\mathrm{n}} \frac{\mathrm{H}_{\mathrm{c}}}{\mathrm{H}_{\mathrm{mac}}}$

Where, $\mathrm{H}_{\mathrm{c}}$ is the monitored value and $\mathrm{H}_{\mathrm{mac}}$ is the maximum admissible concentration (MAC) of ith parameters.

\subsubsection{The degree of contamination $(\mathrm{Cd})$}

The degree of contamination will be used as a reference of estimating the level of pollution. Cd shall be adopted from Backman et al., (1997), and the Cd shall be determined by following the equation as stated below.

$\mathrm{C}_{\mathrm{d}}=\sum_{\mathrm{i} \equiv 1}^{\mathrm{n}} \mathrm{C}_{\mathrm{fi}}$

Where, $\mathrm{Cfi}=(\mathrm{Cai} / \mathrm{Cni})-1$ and $\mathrm{Cfi}$ is the contamination factor, $\mathrm{Cai}$ is the analytical value and $\mathrm{Cni}$ is the upper permissible concentration for the ith component, and $\mathrm{n}$ is indicated for the normative value. Here, Cni is taken as maximum admissible concentration (MAC).

Heavy metal pollution index (HPI), heavy metal evaluation index (HEI) and degree of contamination (Cd) are used to evaluate the hazardous metal pollution for drinking water purposes (Edet and Offiong, 2002; Prasad and Bose, 2001). However, the WQI have limitation. It cannot provide evidence of the pollution sources. The WQI values, thus have to be used together with heavy metal pollution index (HPI), metal evaluation index (HEI) and degree of contamination $(\mathrm{Cd})$ for better assessment of groundwater pollution levels. Water quality indices are therefore useful guidelines for environmental manager, decision makers, and water planners of a definite water system.

Table 1: List of Parameters Weight Factors and Limit Values for the Water Quality Index After Vasanthavigar Et Al., (2010)

\begin{tabular}{|c|c|c|c|c|c|}
\hline S/No & Units & Parameter & Weight $\left(w_{i}\right)$ & Relative weight $\left(\mathrm{W}_{\mathrm{i}}\right)$ & Limit values \\
\hline 1 & & $\mathrm{pH}$ & 4 & 0.078 & $6.5-8.5$ \\
\hline 2 & $\mathrm{mg} / \mathrm{l}$ & $\mathrm{HCO}_{3}$ & 1 & 0.020 & 600 \\
\hline 3 & $\mathrm{mg} / \mathrm{l}$ & $\mathrm{Cl}$ & 3 & 0.059 & 250 \\
\hline 4 & $\mathrm{mg} / \mathrm{l}$ & $\mathrm{F}$ & 4 & 0.078 & 1.5 \\
\hline 5 & $\mathrm{mg} / \mathrm{l}$ & $\mathrm{SO}_{4}$ & 4 & 0.078 & 400 \\
\hline 6 & $\mathrm{mg} / \mathrm{l}$ & $\mathrm{NH}_{4}$ & 3 & 0.059 & 0.5 \\
\hline 7 & $\mathrm{mg} / \mathrm{l}$ & $\mathrm{Na}$ & 4 & 0.078 & 200 \\
\hline 8 & $\mathrm{mg} / \mathrm{l}$ & $\mathrm{K}$ & 2 & 0.039 & 12 \\
\hline 9 & $\mathrm{mg} / \mathrm{l}$ & $\mathrm{Ca}$ & 2 & 0.039 & 75 \\
\hline 10 & $\mathrm{mg} / \mathrm{l}$ & $\mathrm{Mg}$ & 2 & 0.039 & 30 \\
\hline 11 & $\mu \mathrm{g} / \mathrm{l}$ & As & 4 & 0.078 & 50 \\
\hline 12 & $\mu \mathrm{g} / \mathrm{l}$ & $\mathrm{Pb}$ & 4 & 0.078 & 10 \\
\hline 13 & $\mu \mathrm{g} / \mathrm{l}$ & $\mathrm{Fe}$ & 4 & 0.078 & 1000 \\
\hline 15 & $\mu \mathrm{g} / \mathrm{l}$ & $\mathrm{Mn}$ & 4 & 0.078 & 300 \\
\hline 16 & $\mu \mathrm{g} / \mathrm{l}$ & $\mathrm{Al}$ & 3 & 0.059 & 200 \\
\hline \multirow[t]{2}{*}{17} & $\mu \mathrm{g} / \mathrm{l}$ & $\mathrm{Zn}$ & 3 & 0.059 & 5000 \\
\hline & & & $\Sigma \mathrm{w}_{\mathrm{i}}=51$ & $\Sigma \mathrm{W}_{\mathrm{i}}=1$ & \\
\hline
\end{tabular}

\subsubsection{Irrigation water quality}

The following equations were adopted for irrigation water quality indices. The total hardness (TH) shall be evaluated using (Todd and Mays, 2005) equation as

$\mathrm{TH}=2.497 \mathrm{Ca}+4.115 \mathrm{Mg}$

Magnesium hazard (MH) shall be measured using (Szabolc and Darab, 1964) equation as

$\mathrm{MH}=\frac{\mathrm{Mg}}{\mathrm{Ca}+\mathrm{Mg}} \times 100$

The sodium adsorption ratio (SAR) shall be evaluated using (Richards, 1954) equation as

$\mathrm{SAR}=\frac{\mathrm{Na}}{\sqrt{\frac{\mathrm{Ca}+\mathrm{Mg}}{2}}}$

Residual sodium bicarbonate (RSBC) is expressed using (Gupta and Gupta, 1987) equation as $\mathrm{RSBC}=\mathrm{HCO}_{3}{ }^{-}-\mathrm{Ca}^{2+}$

The sodium percentage ( $\mathrm{Na} \%$ ) shall be evaluated using (Vasanthavigar et al., 2010) equation as

$\mathrm{Na} \%=\frac{\mathrm{Na}+\mathrm{K}}{\mathrm{Ca}+\mathrm{Mg}+\mathrm{Na}+\mathrm{K}} \mathrm{X} 100$ 
The permeability indices (PI) shall be evaluated using (Doneen, 1964) equation as

$\mathrm{PI}=\frac{\mathrm{Na}+\sqrt{\mathrm{HCO} 3}}{\mathrm{Ca}+\mathrm{Mg}+\mathrm{Na}} \mathrm{X} 100$

\subsubsection{Principal component analysis (PCA)}

The raw values of the heavy metals were queued into the GenStat analytical program which ran the statistical analysis. The program was set to run the analysis based on the correlation matrix, and to analyse the data in four dimensions, and thereafter display the latent roots, latent vectors (loadings), and principal component scores.

\subsection{T-test}

The comparative analysis and interpretations are based on the T-test statistical analysis carried out on the samples data. A null hypothesis is concerned with the observed differences between the mean of the Surface water (SW) and Groundwater (GW). This is due to the fact surface water is also considered as a source of contaminant to the groundwater. This hypothesis can be rejected and the results regarded as significant if the p-value is less than 0.05 which was the predetermined confidence level. Otherwise, the hypothesis will be accepted and the results will be regarded as insignificant. This comparative analysis is on the assumption that the surface water from where the industries dump their waste (anthropogenic activities) within the study area will contribute to the groundwater quality within the catchment surrounding environment. Then comparative analysis is also on the assumption that the soil from where the industries dump their waste (anthropogenic activities) within the study area will contribute to the groundwater and surface water quality within the catchment surrounding environment. If the difference between the mean of the parameters that were analysed in the surface water (SW) and that of groundwater (GW) is statistically significant, then it implies that the SW has a significant contribution to the GW quality within the study area. Thus, it will be concluded that the industrial (anthropogenic) activities within the study area is contributing significantly to the surrounding GW quality. However, If the difference between the mean of the parameters that were analysed in the surface water (SW)and that of the groundwater $(\mathrm{GW})$ is not statistically significant, it implies that the industrial (anthropogenic) activities within the environment does not contribute significantly to the surrounding GW quality. Hence, insignificant contribution from industrial (anthropogenic) activities could imply that the GW quality is as a result of geogenic factors or not yet from industrial (anthropogenic) activities, but might be over time.

\section{Results}

\subsection{Characteristics of surface water quality}

The result of the surface water analysis of the study area is summarized in Table 2 the three surface water samples in dry season showed that EC values ranged from 19.20 to $35.40 \mu \mathrm{s} / \mathrm{cm}$ with a mean value of $26.63 \mu \mathrm{s} / \mathrm{cm}$. The $\mathrm{pH}$ values of all the samples analyzed in the study area ranges from 5.89 to 6.07 with a mean value of 6.01 , indicating that the surface water in the study area is mostly acidic in nature, which agrees with (Nwakire, 2014). The concentrations of TDS ranges from 4.00 to $10.0 \mathrm{mg} / \mathrm{l}$ with mean value of $6.00 \mathrm{mg} / \mathrm{l}$, based on Carroll (1962), the surface water with TDS between 0.00 to $1047 \mathrm{mg} / \mathrm{l}$ can be classified as fresh water. The concentrations of TSS, and Total hardness ranged from 1.66 to $14.20 \mathrm{mg} / \mathrm{l}$, and 310.00 to $360.00 \mathrm{mg} / \mathrm{l}$ respectively with mean values of $7.38 \mathrm{mg} / \mathrm{l}$ and $330.00 \mathrm{mg} / \mathrm{l} \mathrm{maintaining}$ that sequence. The high values of standard deviation and variance of the total hardness $(26.46 \mathrm{mg} / \mathrm{l}$ and $700.00 \mathrm{mg} / \mathrm{l})$ respectively shows a wide degree in the variability of surface water hardness in the area.

Table 2: Dry Season Surface Water Samples Statistic Summary

\begin{tabular}{|c|c|c|c|c|c|c|}
\hline Parameter & Unit & Minimum & Maximum & Mean & Standard Deviation & Variance \\
\hline $\mathrm{pH}$ & & 5.89 & 6.07 & 6.01 & 0.1 & 0.01 \\
\hline $\mathrm{EC}$ & $\mathrm{us} / \mathrm{cm}$ & 19.2 & 35.4 & 26.63 & 8.18 & 66.94 \\
\hline Hardness & $\mathrm{Mg} / \mathrm{l}$ & 310 & 360 & 330 & 26.46 & 700 \\
\hline TDS & $\mathrm{Mg} / 1$ & 4 & 10 & 6 & 3.46 & 12 \\
\hline Sulphate & $\mathrm{Mg} / \mathrm{l}$ & 45.66 & 49.53 & 47.3 & 2 & 4.01 \\
\hline Chloride & $\mathrm{Mg} / \mathrm{l}$ & 240 & 330 & 276.67 & 47.26 & 2233.33 \\
\hline Bicarbonate & $\mathrm{Mg} / \mathrm{l}$ & 6 & 14 & 8.67 & 4.62 & 21.33 \\
\hline Nitrate & $\mathrm{Mg} / \mathrm{l}$ & 2.2 & 2.5 & 2.3 & 0.17 & 0.03 \\
\hline TSS & $\mathrm{Mg} / \mathrm{l}$ & 1.6 & 14.2 & 7.38 & 6.36 & 40.5 \\
\hline $\mathrm{Cr}$ & Ppm & 0 & 6.68 & 2.49 & 3.65 & 13.34 \\
\hline $\mathrm{Ni}$ & Ppm & 0.2 & 0.49 & 0.3 & 0.16 & 0.03 \\
\hline As & Ppm & 0.03 & 0.13 & 0.07 & 0.06 & 0 \\
\hline $\mathrm{Fe}$ & Ppm & 8.77 & 11.62 & 10.13 & 1.43 & 2.05 \\
\hline $\mathrm{Cd}$ & $\mathrm{Ppm}$ & 0.02 & 0.03 & 0.03 & 0.01 & 0 \\
\hline $\mathrm{Pb}$ & Ppm & 0.32 & 0.39 & 0.36 & 0.03 & 0 \\
\hline $\mathrm{Hg}$ & $\mathrm{Ppm}$ & 0.18 & 0.19 & 0.18 & 0.01 & 0 \\
\hline $\mathrm{Al}$ & Ppm & 0 & 0.74 & 0.25 & 0.43 & 0.18 \\
\hline $\mathrm{Ca}$ & $\mathrm{Ppm}$ & 6.35 & 15.19 & 9.32 & 5.08 & 25.81 \\
\hline $\mathrm{Mg}$ & Ppm & 10.22 & 15.89 & 12.15 & 3.24 & 10.52 \\
\hline $\mathrm{Na}$ & Ppm & 8.33 & 9.49 & 8.75 & 0.64 & 0.41 \\
\hline $\mathrm{K}$ & Ppm & 7.24 & 8.27 & 7.62 & 0.56 & 0.32 \\
\hline
\end{tabular}

\subsection{Classification of the surface water into various irrigation quality indices}

Since the surface water in the study area are being used for irrigation around the water bodies, for accomplishing maximum crop productivity, the water used for irrigation should be of good quality. Thus, for classification and evaluation of surface water quality, the chemical parameters play a significant role. Therefore, to assess water quality for different uses, irrigation water quality indices such as Sodium Adsorption Ratio, Kelly's Ratio, Magnesium Hazard, Percent Sodium, permeability index and Residual Sodium Bicarbonate were calculated from the chemical analyses of three surface water samples in the study area. 
Sodium Adsorption Ratio (SAR): The SAR values ranges from1.9 to 2.2ppm and according to the Richards (1954) classification of SAR $<10 \%, 10-18 \%, 18.1 \%-26 \%$ and $>26 \%$ values belong to the excellent, good, fair and poor categories, respectively. (Tables 3 ). However, all of the samples were found excellent for irrigation for dry season as per this classification.

Kelly's Ratio (KR): KR greater than 1 shows an excess of sodium, and KR less than 1 signifies its deficit in water (Kelly 19863). Table 3 shows KR values of surface water varied from 0.3 to 0.5 for dry season samples therefore, surface water analysed is suitable for irrigation in accordance with Kelly's ratio.

Magnesium Hazard (MH): Magnesium ratio is also important to assess the suitability of water quality for irrigation. Magnesium damages soil structure when water contains more sodium and high salinity (Chidambaram et al., 2013). Magnesium hazard less than 50 is considered suitable for irrigation whereas greater than 50 are unsuitable for irrigation, decreasing the yield of crops and making the soil more alkaline (Szabolc and Darab, 1964). The values of MH in the study area for dry season varied from 52 to 67 indicating that the water is unsuitable in the dry season

Percent Sodium (Na \%): As per the classification suggested by Wilcox (1955) for Na\%, the value of <60 in groundwater is suitable for irrigation purposes. The percent sodium values of the study area varied from 48 to $58 \%$ in the dry season indicating that Na\% is within permissible limits for irrigation purposes

Permeability Index (PI): PI is a significant parameter for surface with relation to the soil for improvement of agriculture. Sodium, bicarbonate, calcium, and magnesium concentration in the soil are more responsible for influencing the soil permeability (Selvakumara et al., 2017). Permeability index is a crucial parameter for assessing the suitability of irrigation water. In accordance with PI, water of value $>75$, $25-75$, and $<25$ can be classified as Excellent, good and unsuitable respectively (Table 3 ). PI values of the surface water sample for the dry season samples are all unsuitable with respect to PI values.

Residual Sodium Bicarbonate (RBSC): according to Gupta and Gupta (1987) RBSC values, less than 5 is considered suitable for irrigation whereas greater than 5 is unsuitable for irrigation. RBSC values for surface water in the study area are all more than 5 , which makes it not suitable for irrigation.

Table 3: Interpretation of Surface Water Irrigation Indices

\begin{tabular}{|c|c|c|c|c|c|}
\hline Index method & Category & Water class & No of locations & $\%$ of samples & Samples \\
\hline \multirow[t]{4}{*}{ SAR } & $<10$ & Excellent & 3 & 100 & SW1, SW2 \& SW3 \\
\hline & $10.0-18$ & Good & & & \\
\hline & $18.1-26$ & Fair & & & \\
\hline & $>26$ & Poor & & & \\
\hline \multirow[t]{2}{*}{ KR } & $<1$ & Suitable & 3 & 100 & SW1, SW2 \& SW3 \\
\hline & $>1$ & Unsuitable & & & \\
\hline \multirow[t]{2}{*}{ MH } & $<50$ & Acceptable & & & \\
\hline & $>50$ & Unacceptable & 3 & 100 & SW1, SW2 \& SW3 \\
\hline \multirow[t]{5}{*}{$\mathrm{Na} \%$} & $<20$ & Excellent & & & \\
\hline & $20-40$ & Good & 1 & 33.3 & SW1 \\
\hline & $40-60$ & Permissible & 2 & 66.7 & SW2 \&SW3 \\
\hline & $60-80$ & Doubtful & & & \\
\hline & $>80$ & Unsuitable & & & \\
\hline \multirow[t]{3}{*}{ PI } & $>75$ & Excellent & & & \\
\hline & $25-75$ & Good & & & \\
\hline & $<25$ & Unsuitable & 3 & 100 & SW1, SW2 \& SW3 \\
\hline \multirow[t]{2}{*}{ RSBC } & $<5$ & Safe & & & \\
\hline & $>5$ & Unsuitable & 3 & 100 & SW1, SW2 \& SW3 \\
\hline
\end{tabular}

\subsection{General characteristics of groundwater quality}

General characteristics of groundwater physical parameters, heavy metals and major cations and anions for the study area are summarized in Table 4. below with mean, maximum, minimum, standard deviation values and Variance. All the 22 samples in dry season showed the EC values ranged from 8.10 to $50.20 \mu \mathrm{s} / \mathrm{cm}$ with a mean value of $26 \mu \mathrm{s} / \mathrm{cm}$. The $\mathrm{pH}$ values of all the samples analysed in the study area ranges from 5.82 to 6.49 with a mean value of 6.17 , indicating that the groundwater in the study area is slightly acidic in nature, which is in agreement with result of the study area (Egbunike and Okpoko, 2018). TDS ranged from 1.00 to $17.00 \mathrm{mg} / \mathrm{l}$ with mean values of $3.00 \mathrm{mg} / \mathrm{l}$, which is still within the Nigerian Industrial Standard, (2007) and WHO (2011) recommended limit for safe drinking water. Total hardness ranged from 12 to $580 \mathrm{mg} / \mathrm{l}$ with mean values of $282.00 \mathrm{mg} / \mathrm{l}$ which is above the Nigerian Industrial Standard, (2007) permissible limit of potable water, the implications for consumption of hard water is that it can cause cardiovascular disease, growth retardation, and reproductive failure (Sengupta, 2013).

Table 4: Groundwater Samples Statistic Summary

\begin{tabular}{|c|c|c|c|c|c|c|c|c|}
\hline Parameter & Unit & Minimum & Maximum & Mean & Standard Deviation & Variance & WHO (2011) & NSDWQ \\
\hline $\mathrm{Ph}$ & & 5.82 & 6.49 & 6.17 & 0.19 & 0.03 & $6.5-8.5$ & $6.5-8.5$ \\
\hline $\mathrm{EC}$ & $\mathrm{us} / \mathrm{cm}$ & 8.1 & 52.50 & 26.01 & 13.50 & 182.33 & - & - \\
\hline Hardness & $\mathrm{Mg} / \mathrm{l}$ & 12 & 580.00 & 282.27 & 148.35 & 22007.73 & & 150 \\
\hline TDS & $\mathrm{Mg} / \mathrm{l}$ & 1 & 17.00 & 3.07 & 3.46 & 11.94 & - & 500 \\
\hline TSS & $\mathrm{Mg} / \mathrm{l}$ & 0.22 & 29.20 & 1.90 & 6.12 & 37.42 & - & - \\
\hline $\mathrm{Cr}$ & Ppm & 0 & 0.89 & 0.38 & 0.32 & 0.10 & 0.05 & 0.05 \\
\hline $\mathrm{Ni}$ & Ppm & 0.04 & 0.38 & 0.24 & 0.10 & 0.01 & 0.07 & 0.02 \\
\hline As & Ppm & 0 & 0.32 & 0.04 & 0.08 & 0.01 & 0.01 & 0.01 \\
\hline $\mathrm{Fe}$ & Ppm & 0 & 0.00 & 0.00 & 0.00 & 0.00 & & 0.3 \\
\hline $\mathrm{Cd}$ & Ppm & 0 & 0.06 & 0.02 & 0.02 & 0.0005 & 0.003 & 0.003 \\
\hline $\mathrm{Hg}$ & Ppm & 0.006 & 168.00 & 7.86 & 35.77 & 1279.28 & 0.006 & 0.001 \\
\hline $\mathrm{Al}$ & Ppm & 0 & 1.27 & 0.38 & 0.45 & 0.21 & - & 0.2 \\
\hline $\mathrm{Pb}$ & Ppm & 0.009 & 0.47 & 0.19 & 0.12 & 0.01 & 0.1 & 0.01 \\
\hline $\mathrm{Ca}$ & Ppm & 0 & 5.06 & 0.67 & 1.37 & 1.87 & 75 & 75 \\
\hline $\mathrm{Na}$ & Ppm & 0.91 & 6.31 & 4.36 & 1.74 & 3.03 & 40 & 200 \\
\hline $\mathrm{Mg}$ & Ppm & 0 & 6.71 & 1.30 & 2.08 & 4.32 & - & 20 \\
\hline $\mathrm{K}$ & Ppm & 3.019 & 7.27 & 4.83 & 1.12 & 1.25 & _ & 200 \\
\hline
\end{tabular}




\begin{tabular}{|c|c|c|c|c|c|c|c|c|}
\hline $\mathrm{SO}_{4}{ }^{2-}$ & $\mathrm{Mg} / \mathrm{l}$ & 0.911 & 6.22 & 4.82 & 1.54 & 2.37 & 500 & 100 \\
\hline $\mathrm{Cl}^{-}$ & $\mathrm{Mg} / \mathrm{l}$ & 130 & 540.00 & 225.00 & 96.00 & 9216.67 & - & 250 \\
\hline $\mathrm{HCO}_{3}^{-}$ & $\mathrm{Mg} / \mathrm{l}$ & 4 & 8.00 & 5.64 & 1.00 & 1.00 & - & 120 \\
\hline $\mathrm{NO}_{3}^{-}$ & $\mathrm{Mg} / \mathrm{l}$ & 0.02 & 3.30 & 1.15 & 0.83 & 0.69 & $\overline{5} 0$ & 50 \\
\hline
\end{tabular}

\subsection{Evaluation of drinking water quality}

The groundwater quality index (GWQI) is a mathematical technique used to transform large quantities of water quality data into a single number which represents the water quality level. In this study, the Nigerian Industrial Standard, (2007) and WHO (1996) drinking water standard were used to determine the suitability of the groundwater quality for drinking purposes.

\begin{tabular}{|c|c|c|c|c|c|}
\hline $\begin{array}{l}\text { Index } \\
\text { metho } \\
\text { d }\end{array}$ & $\begin{array}{l}\text { Cate- } \\
\text { gory }\end{array}$ & $\begin{array}{l}\text { Degree of pollu- } \\
\text { tion water class }\end{array}$ & $\begin{array}{l}\text { Number of } \\
\text { locations }\end{array}$ & $\begin{array}{l}\% \text { of } \\
\text { sam- } \\
\text { ple }\end{array}$ & Samples \\
\hline \multirow[t]{5}{*}{ GWQI } & $<50$ & Excellent water & 0 & 0 & \\
\hline & $\begin{array}{l}50- \\
100\end{array}$ & Good water & 0 & 0 & \\
\hline & $\begin{array}{l}100.1 \\
-200\end{array}$ & Poor water & 0 & 0 & \\
\hline & $\begin{array}{l}200.1 \\
-300\end{array}$ & Very poor water & 1 & 4.6 & GW6 \\
\hline & $>300$ & $\begin{array}{l}\text { Water unsuita- } \\
\text { ble for drinking }\end{array}$ & 21 & 95.4 & $\begin{array}{l}\text { GW1, GW2, GW3, GW4, GW5, GW7, GW8, GW9, GW10, GW11, GW12, GW13, } \\
\text { GW14, GW15, GW16, GW17, GW18, GW19 GW20, GW21 \&GW22 }\end{array}$ \\
\hline \multirow[t]{3}{*}{ HPI } & $<45$ & Low & 0 & & \\
\hline & $\begin{array}{l}45- \\
90\end{array}$ & Medium & 0 & & \\
\hline & $>90$ & High & 22 & 100 & $\begin{array}{l}\text { GW1, GW2, GW3, GW4, GW5, GW6, GW7, GW8, GW9, GW10, GW11, GW12, } \\
\text { GW13, GW14, GW15, GW16, GW17, GW18, GW19 GW20, GW21 \&GW22 }\end{array}$ \\
\hline \multirow[t]{3}{*}{ HEI } & $<10$ & Low & 0 & & \\
\hline & $\begin{array}{l}10.0 \\
-20\end{array}$ & Medium & 0 & & \\
\hline & $>20$ & High & 22 & 100 & $\begin{array}{l}\text { GW1, GW2, GW3, GW4, GW5, GW6, GW7, GW8, GW9, GW10, GW11, GW12, } \\
\text { GW13, GW14, GW15, GW16, GW17, GW18, GW19 GW20, GW21 \&GW22 }\end{array}$ \\
\hline \multirow[t]{3}{*}{$\mathrm{Cd}$} & $<10$ & Low & 0 & & \\
\hline & $\begin{array}{l}10.0 \\
-20\end{array}$ & Medium & 0 & & \\
\hline & $>20$ & High & 22 & 100 & $\begin{array}{l}\text { GW1, GW2, GW3, GW4, GW5, GW6, GW7, GW8, GW9, GW10, GW11, GW12, } \\
\text { GW13, GW14, GW15, GW16, GW17, GW18, GW19 GW20, GW21 \&GW22 }\end{array}$ \\
\hline
\end{tabular}

\subsection{Principal component analysis for groundwater sample}

Heavy metals from groundwater analytical results were used to carry out the principal component analysis which is a multivariate analysis. The physicochemical parameters, anions and cations was not use because heavy metal is more of industrial contaminant and are more harmful to human health. The heavy metals also exceeded Nigerian Industrial Standard, (2007) and WHO (2011) standards in most locations. The Analysis will help determine the pattern that exists in the data and also to express the data in such a way as to highlight their similarities and differences. The implication of the principal component analysis as presented in Table 6 reveals the location where these principal components predominate.

Table 6: A) Dry Season PCA Results Showing Heavy Metals That Affects Groundwater Quality and Their Dimension of Influence

\begin{tabular}{|c|c|c|c|c|}
\hline Dimension & First & Second & Third & Fourth \\
\hline Principal Component (PC) & $\mathrm{PC} 1$ & $\mathrm{PC} 2$ & PC3 & PC4 \\
\hline Heavy metals that is contributing to the groundwater quality index & $\mathrm{As}, \mathrm{Pb}$ & $\mathrm{Al}$ & $\mathrm{Hg}$ & $\mathrm{Ni}$ \\
\hline Latent roots & 2 & 1 & 1 & 1 \\
\hline Percentage variation & 30 & 19 & 16 & 14 \\
\hline
\end{tabular}

Table 6: B) Dry Season Principal Component Analysis Results Showing Chemical Elements That Affects Groundwater Quality and Locations of Their Influence

\begin{tabular}{|c|c|c|c|c|}
\hline Location & $\mathrm{PC} 1$ & $\mathrm{PC} 2$ & PC3 & PC4 \\
\hline 1 & & $X$ & & \\
\hline 2 & $\mathrm{X}$ & & & $\mathrm{X}$ \\
\hline 3 & & & $X$ & \\
\hline 4 & & & $X$ & \\
\hline 5 & $\mathrm{X}$ & $X$ & & \\
\hline 6 & $\mathrm{X}$ & & $X$ & \\
\hline 7 & & $X$ & & $X$ \\
\hline 8 & $\mathrm{X}$ & & $X$ & $\mathrm{X}$ \\
\hline 9 & $X$ & & & \\
\hline 10 & & & $X$ & \\
\hline 11 & & $X$ & & \\
\hline 12 & & $X$ & & \\
\hline 13 & & & $X$ & \\
\hline 14 & $X$ & & $X$ & \\
\hline 15 & $\mathrm{X}$ & & $X$ & \\
\hline 16 & & & & $X$ \\
\hline 17 & & $X$ & & \\
\hline
\end{tabular}




\begin{tabular}{llll}
\hline 18 & $\mathrm{X}$ & $\mathrm{X}$ & $\mathrm{X}$ \\
19 & $\mathrm{X}$ & $\mathrm{X}$ & \\
20 & & $\mathrm{X}$ & $\mathrm{X}$ \\
21 & & & \\
22 & & & \\
\hline
\end{tabular}

\subsection{Comparative analysis between surface water $(\mathrm{SW})$ and groundwater $(\mathrm{GW})$}

Table 7 revealed that the mean concentration of $\mathrm{Cd}$ and $\mathrm{Al}$ in SW is slightly higher than that of the GW. But this difference is statistically insignificant; as a result, the increase in $\mathrm{Cd}$ and $\mathrm{Al}$ in the $\mathrm{GW}$ is not associated with $\mathrm{Cd}$ and $\mathrm{Al}$ in the $\mathrm{SW}$. However, the mean concentration of $\mathrm{Cr}, \mathrm{Fe}$ and $\mathrm{Hg}$ in $\mathrm{SW}$ is higher than that in GW. This observed variation is statistically significant; hence, surface water within the environment has a significant contribution to the concentration level of $\mathrm{Cr}, \mathrm{Fe}, \mathrm{Pb}$ and $\mathrm{Hg}$ in the surrounding groundwater

Table 7: Comparison Between Heavy Metal from SW and GW Dry Season

\begin{tabular}{llllll}
\hline Parameter & Mean SW & Mean GW & $\mathrm{p}-$ Value & $\mathrm{a}-$ Value & Significance \\
\hline $\mathrm{Cr}$ & 0.229 & 0.104 & 0.000001 & 0.05 & SIG \\
$\mathrm{Fe}$ & 0.096 & 0.236 & 0.596907 & 0.05 & SIG \\
$\mathrm{Cd}$ & 0.358 & 0.154 & 0.584450 & 0.05 & NOT SIG \\
$\mathrm{Hg}$ & 0.000 & 0.059 & 0.048052 & 0.05 & SIG \\
$\mathrm{Al}$ & 0.027 & 0.002 & 0.447028 & 0.05 & NOT SIG \\
$\mathrm{Pb}$ & 0.000 & 0.028 & 0.012410 & 0.05 & SIG \\
\hline
\end{tabular}

\section{Discussion}

The concentration of heavy metals $\mathrm{Cr}, \mathrm{Ni}, \mathrm{As}, \mathrm{Fe}, \mathrm{Cd}, \mathrm{Pb}, \mathrm{Hg}$ and $\mathrm{Al}$ were found to range from 0.00 to $06.68 \mathrm{ppm}, 0.20$ to $0.49 \mathrm{ppm}, 0.03$ to $0.13 \mathrm{ppm}, 8.77$ to $11.62 \mathrm{ppm}, 0.02$ to $0.03 \mathrm{ppm}, 0.32$ to $0.39 \mathrm{ppm}, 0.18$ to $0.19 \mathrm{ppm}$ and 0.01 to $0.74 \mathrm{ppm}$ respectively. The mean concentration of the heavy metals analysed followed the descending order: $\mathrm{Ni}>\mathrm{Cd}>\mathrm{Pb}>\mathrm{As}>\mathrm{Hg}>\mathrm{Al}>\mathrm{Cr}>\mathrm{Fe}$. However, the mean values of the major Cations and Anions analysed in this study are below permissible limits of WHO (2011) drinking water standards. The Cations $\left(\mathrm{Ca}, \mathrm{Mg}, \mathrm{Na}\right.$ and $\mathrm{K}$ ) have mean values of $9.32 \mathrm{ppm}, 12.15 \mathrm{ppm}, 8.75 \mathrm{ppm}$ and 7.62ppm respectively while the $\mathrm{Anions}\left(\mathrm{Cl}^{-}, \mathrm{NO}_{3}^{-}, \mathrm{SO}_{4}\right.$ and $\mathrm{HCO}_{3}$ ) have mean values of $276 \mathrm{ppm}, 2.30 \mathrm{ppm}, 47.30 \mathrm{ppm}$ and $8.67 \mathrm{ppm}$ respectively.

The concentration of heavy metals of $\mathrm{Cr}, \mathrm{Ni}, \mathrm{As}, \mathrm{Fe}, \mathrm{Cd}, \mathrm{Hg}, \mathrm{Al}$ and $\mathrm{Pb}$ were found to range from 0.00 to $0.89 \mathrm{ppm}, 0.04$ to $0.38 \mathrm{ppm}, 0.00$ to $0.35 \mathrm{ppm}, 0.00$ to $0.00 \mathrm{ppm}, 0.00$ to $0.06 \mathrm{ppm}, 0.01$ to $168.00 \mathrm{ppm}, 0.00$ to $1.27 \mathrm{ppm}$ and 0.01 to $0.47 \mathrm{ppmrespectively}$. The mean concentration of the heavy metals analysed followed the descending order: $\mathrm{Fe}>\mathrm{Cd}>\mathrm{Cr}>\mathrm{As}>\mathrm{Pb}>\mathrm{Ni}>\mathrm{Al}>\mathrm{Hg}$. Moreover, the mean value of $\mathrm{Cr}(0.38), \mathrm{Ni}(0.24), \mathrm{As}(0.04), \mathrm{Cd}(0.02), \mathrm{Hg}(7.86), \mathrm{Al}(0.38)$ and $\mathrm{Pb}(0.19)$ exceeded the permissible limit for Nigerian Industrial $\mathrm{Standard}$, (2007) and WHO (2011) recommended limit for safe drinking water, which may cause serious health hazard such as cancer, liver disease and so many other health issues (Botlagunta et al., 2015). It is observed that most of the groundwater samples revealed the high concentrations of $\mathrm{Cr}, \mathrm{Ni}, \mathrm{As}, \mathrm{Cd}, \mathrm{Hg}, \mathrm{Al}$ and $\mathrm{Pb}$ values in the study area. The Cations ( $\mathrm{Ca}, \mathrm{Mg}, \mathrm{Na}$ and $\mathrm{K}$ ) have mean values of $0.67 \mathrm{ppm}, 1.30 \mathrm{ppm}$, 5.09ppm and 4.83ppm respectively while the Anions $\mathrm{Cl}^{-}, \mathrm{SO}_{4}{ }^{2-}, \mathrm{NO}_{3}{ }^{-}$and $\mathrm{HCO}_{3}$ ) have mean values of 225.00ppm, 4.82ppm, 1.15ppm and $6.00 \mathrm{ppm}$ respectively, which are below Nigerian Industrial Standard, (2007) and WHO (2011) recommended limit for safe drinking water expect for $\mathrm{Cl}^{-}$which is above the Nigerian Industrial Standard, (2007). permissible limits. The effect of excess $\mathrm{Cl}^{-}$in drinking water has been proven to cause serious health issues, including damage to the immune, respiratory, neurological, and reproductive systems and other health problems like cancer (Botlagunta et al., 2015).

The GWQI index revealed that about $95.4 \%$ of the groundwater samples are unsuitable for drinking, while only about $4.6 \%$ of the samples are of very poor quality. (Table 5). The heavy metals $\mathrm{Cr}, \mathrm{Ni}, \mathrm{As}, \mathrm{Cd}, \mathrm{Hg}, \mathrm{Al}$ and $\mathrm{Pb}$, were used to calculate heavy metal pollution index HPI, HEI and $C_{d}$. The HPI, HEI and $C_{d}$ revealed that $100 \%$ of the groundwater samples showed high pollution index/ evaluation index. These results clearly reveal that the dry season groundwater samples are more polluted than the rainy season. This may be due to the dilution of metal concentration in groundwater by infiltration during the rainy season.

For the PCA of dry season samples Table 6b, it was observed that in PC1, location 1, 11, 12, 17 and 21 only the heavy metal in PC2 is contributing to the groundwater quality, whereas at location 2 and 18, the heavy metals in PC1 and PC4 are contributing to the groundwater quality. At location 4, 10, 13, 20 and 22 only the heavy metal in PC3 is contributing to the groundwater quality whereas at location 5, the heavy metals in PC1 and PC2 are contributing to the groundwater quality, in location 10, only the heavy metal in PC3 is contributing to the groundwater quality, in location 6,14 and 15, the heavy metals in PC1 and PC3 are contributing to the groundwater quality. Then for location 7 the heavy metals in PC2 and PC4 are contributing to the groundwater quality, more so for location 8 and 19, the heavy metals in PC1, PC3 and PC4 are contributing to the groundwater quality. While in location 9 and 16, the heavy metals in PC1 and PC4 respectively are contributing to the groundwater quality.

\section{Conclusion}

Upon completion of the assessment of water quality in parts of industrial areas in Nnewi North Local Government Area, South East Nigeria, it was discovered that the study area is underlain by Nanka Sand and Ogwashi-Asaba formation. Groundwater is moderately available, it is acidic, and contaminated in the dry season with heavy metal such as $\mathrm{Cd}, \mathrm{Ni}, \mathrm{As}, \mathrm{Cd}, \mathrm{Hg}, \mathrm{Al}$, and $\mathrm{Pb}$ exceeded the permissible limit for WHO (2011) and Nigerian Industrial Standard, (2007) drinking water standard. The mean concentration of the heavy metals analysed followed the descending order: $\mathrm{Fe}>\mathrm{Cd}>\mathrm{Cr}>\mathrm{As}>\mathrm{Pb}>\mathrm{Ni}>\mathrm{Al}>\mathrm{Hg}$. The GWQI ranges from very poor to unsuitable for drinking and HPI, HEI, and Cd revealed that the water is highly contaminated.

The surface water is highly polluted with heavy metal. The irrigation eminence indices show that the surface water is suitable for irrigation in terms of SAR, KR, Na\% and hardness but unsuitable with respect to RBSC and PI.

\section{Abbreviations}

SW:

Surface water 


$\begin{array}{ll}\text { GW: } & \text { Groundwater } \\ \text { SIG: } & \text { Significance } \\ \text { NOT SIG: } & \text { Not Significance } \\ \text { PCA: } & \text { Principal Component Analysis } \\ \text { NSDWQ: } & \text { Nigerian Standard for Drinking Water Quality } \\ \text { WHO: } & \text { World Health Organisation? } \\ \text { TH: } & \text { Total Hardness } \\ \text { MH: } & \text { Magnesium Hazard } \\ \text { SAR: } & \text { Sodium adsorption ratio } \\ \text { Na } \%: & \text { Sodium Percentage } \\ \text { PI: } & \text { Permeability Indices } \\ \text { GWQI: } & \text { Groundwater Quality Index } \\ \text { HPI: } & \text { Heavy Metal Pollution Index } \\ \text { HEI: } & \text { Heavy Metal Evaluation Index } \\ \text { Cd: } & \text { Degree of Contamination }\end{array}$

\section{References}

[1] Akarinwo, J. \& Gwin, O. (2006). Effect on microbial load on Indofood (Indomie) Effluent Discharge on Physiochemical property of New Calabar River in Choaba. JN Environ, 313: 195 - 204.

[2] AN-NEWMAP (2017). Anambra Nigeria Erosion and Watershed Management Project.

[3] Backman, B. Bodis, D. Lahermo, P. Rapant, S. \& Tarvainen, T. (1997). Application of a groundwater contamination index in Finland and Slovakia. Environ. Geol. 36, 55-64.https://doi.org/10.1007/s002540050320.

[4] Bamidele, C. (2015). Impact of Effluent Waste on the Environment Academia. Edu https://www.academia.edu.

[5] Botlagunta, M. Bondili, J. \& Mathi, P. (2015). Water Chlorination and Its Relevance to Human Health. Asian J Pharm Clin Res, 8(1): $20-24$.

[6] Carroll, D. (1962). Rainwater as a chemical agent of Geologic processes a review, U.S Geological Survey water supply paper $1535-G$ : 18.

[7] Chidambaram, M. Prasad, R. Manivannam, U. Karmegam, C. \& Singaraja, B. (2013). Environmental hydrogeochemistry and genesis of fluoride in groundwaters of Dindugal district, Tamil Nadu, India. Environ. Earth Sci. 68(2): 333-342https://doi.org/10.1007/s12665-012-1741-9.

[8] Egbunike, M.E. \& Okpoko, E.I. (2018). Hydrogeochemical Investigation of Surface Water and Groundwater Resources in Nnewi and Environs of Anambra Basin, Nigeria. J. Envir. Earth Sci., 8(3): 2224-3216.

[9] Doneen, L.D. (1964). Notes on water quality in agriculture. In Davis, C.A., Water Science and Engineering, University of California.

[10] Edet, A.E. \& Offiong, O.E. (2002). Evaluation of water quality pollution indices for heavy metal contamination monitoring. A study case from Akpabuyo-Odukpani area, Lower Cross River Basin (southeastern Nigeria). Geo. Journal 5: 295304https://doi.org/10.1023/B:GEJO.0000007250.92458.de.

[11] Gupta, S.K. \& Gupta, I.C. (1987). Management of saline soils and water. Oxford and IBH Publication Coy, New Delhi, India.

[12] Kelly, W.P. (1963). Permissible Composition and Concentration of Irrigated Waters. Proceedings of the American Society of Civil Engineers, 66:607613 https://doi.org/10.14219/jada.archive.1963.0161.

[13] Lakhimi, G. (2010). Industrial Effluents and Their Impact on Ground Water Quality and Human Health in Guwahati City, India: Innovative Energy Technology Systems and Environmental Concerns: A Sustainable Approach Isbn: 978-93-84144-81-4107.

[14] Mahajan, G.D. (2012). Hydrogeochemistry of Sukhana River subbasin of Aurangabad district, INDIA. Int. J. Recent Trends Sci. Tech. 4(1), 01-04.

[15] Mohan, S.V. Nithila, P. \& Reddy, S.J. (1996). Estimation of heavy metals in drinking water and development of heavy metal pollution index. J. Environ. Sci. Health Part A 31: 283-289https://doi.org/10.1080/10934529609376357.

[16] Nigerian Industrial Standard, (2007). Nigerian Standard for Drinking Water Quality, SON Governing Council, NIS 554: 2007.

[17] Nwajide, C.S. (1979). A Lithostratigraphic Analysis of Nanka Sands, Southern Nigeria. J. Min. Geol. Nig. 2: $103-108$.

[18] Nwajide, C.S. (2013). Geology of Nigeria’s Sedimentary Basins. CSS Bookshops Ltd, 565p.

[19] Nwakire, K.L. (2014). The Effects of Industrial Discharges on Water Bodies: A Case Study of MmiriEle in Nnewi Anambra State Nigeria. Int. J. Life Sci. Res. 2 (3), 56-68.

[20] Obeta, M. C. (2015). Industrial Water Supply in Nnewi Urban Area of Anambra State, South Eastern, Nigeria. J. Geog. Envir. Earth Sci. Inter. 2(1): 12-23https://doi.org/10.9734/JGEESI/2015/14538.

[21] Okpoko, E. I. (2017). Hydrogeologic Evaluation and Modelling of Aquifer Systems in Amichi-Amesi Area of Southeast Nigeria. J. of Phy. Sci. 1, (1). 113 .

[22] Onunkwo, A.A. Nwagbara, J.O. \& Ahiarakwem, C.A. (2014). Assessment of heavy metals in Nnewi groundwater. Int. J. Eng. Res. Dev. 10(11): 0109.

[23] Orisakwe, O.E. Asomugha, R. Atomic, O.J. Obi, B. Chilaka, K.C. \& Dioka, C. (1999). Effect of industrial effluents on water soil qualities in Nnewi. Nigeria. J. Health Sci. 45: 177- 183.

[24] Prasad, B. \& Jaiprakas, K.C. (1999). Evaluation of heavy metals in ground water near mining area and development of heavy metal pollution index. J. Environ. Sci. Health A34: 91-102https://doi.org/10.1080/10934529909376825.

[25] Prasad, B. \& Bose, J. (2001). Evaluation of heavy metals pollution index for surface water near a limestone mining area of the lower Himalayas. J. Environ. Sci. Health 41: 183-188https://doi.org/10.1007/s002540100380.

[26] Reyment, R.A. (1965). Aspects of the geology of Nigeria. Ibadan University press, Nigeria.

[27] Richards, L.A. (1954). Diagnosis and improvement of saline and alkaline soils. US Department of Agriculture Handbook, Nigeria.

[28] Sarker, B. (2014). Assessment of Industrial Effluents Quality: A Case Study of Bhaluka Industrial Area, Mymensingh, Bangladesh. Bangladesh J. of Environ. Sci., $146-4$.

[29] Selvakumara, S. Chandrasekara, N. \& Kumarb, G. (2017). Hydrogeochemical characteristics and groundwater contamination in the rapid urban development areas of Coimbatore, India. Water Resources and Industry 17: 26-33. https://doi.org/10.1016/j.wri.2017.02.002

[30] Sengupta, P. (2013). Potential Health Impacts of Hard Water Int J Prev Med 4:866-75.

[31] Szabolcs, I. \& Darab, C. (1964). The influence of irrigation water of high sodium carbonate content of soils. In: Proceedings of 8th International Congress of ISSS, Transmission, 2: 803-812.

[32] Todd, D.K. \& Mays, L.W. (2005) Groundwater hydrology. John wiley and sons, Inc, 3rd ed, USA.

[33] Vasanthavigar, M. Srinivasamoorthy, K. \& Chidambaram, S. (2010). Application of Water Quality Index for Groundwater Quality Assessment: Thirumanimuttar Sub-Basin, Tamilnadu, India. Environmental Monitoring and Assessment, 171: 595-609.https://doi.org/10.1007/s10661-009-13021.

[34] WHO, (1996)? Guidelines for drinking water quality, 2,2 ${ }^{\text {nd }}$ Ed., World Health Organization, Geneva.

[35] WHO (2011)? Guidelines for Drinking Water Quality ( ${ }^{\text {th }}$ Edition) World Health Organisation, Geneva.

[36] Wilcox, L.V. (1955). Classification and use of irrigation waters. US Department of Agriculture, Washington. USA. 